\title{
Design Experiments for Biosorption of Lead Ions from Wastewater by Box-Wilson's Method
}

\author{
Jaafar Zaki Yahya ${ }^{1}$, and Hussain Majeed Flayeh ${ }^{2, *}$ \\ ${ }^{1}$ Department of Environmental Engineering, University of Baghdad, Baghdad, Iraq, jaafaraladily@yahoo.com \\ ${ }^{2}$ Department of Environmental Engineering, University of Baghdad, Baghdad, Iraq, hussmf200211@yahoo.com \\ *Corresponding author: Jaafar Zaki Yahya, email: jaafaraladily@yahoo.com \\ Published online: 30 June 2019
}

Abstract-Box-Wilson's method of design of experiments was used to maximize heavy metal removal from synthetic wastewater. The process of optimization was based on four independent pertinent parameters: agitation speed (150-250) rpm, initial metal concentration (20-40) mg/l, pH (4-8), and biomass dose (2-4) $\mathrm{g} / \mathrm{l}$. Lead was chosen as heavy metal. A maximum biosorption was practically attained following thirty runs of different experiments, as given by 24 - Central Composite Design (CCD). The best conditions were initial metal concentration $25.29 \mathrm{mg} / \mathrm{l}, \mathrm{pH} 5.78$, biomass dose $3.36 \mathrm{~g} / \mathrm{l}$, agitation speed $209.21 \mathrm{rpm}$. The gained data of experiments were used to form a semiempirical model, based upon a quadratic polynomial, to foretell lead ions biosorption. The model was examined using a statistical software (Design Expert ${ }^{\circledR}$ 11.0) and found adequate. Biosorption response surfaces and contour plots were generated using the developed model, which exposed the existence of high biosorption plateaus whose specifications will be beneficial in monitoring industrial scale or pilot-scale units of future to confirm economic achievability.

Keywords- Lead ions, Dead Anaerobic Sludge, Response Surface Methodology, Analysis of Variance.

\section{Introduction}

There are numerous water pollution sources, but two principal categories are: indirect and direct pollutant sources. Indirect sources involve pollutants that enter the water supply from the atmosphere via rain water, from systems of soil water and groundwater systems; whereas, direct sources involve effluent outfalls from industries, refineries and waste treatment plants. Generally, pollutants come under two main classes, via inorganic and organic. Inorganic water contaminants include heavy metals and fertilizers discharged from industrial and agricultural processes. Some organic water pollutants involve industrial solvents, volatile organic compounds, insecticides and pesticides, etc. [26].

Heavy metals are defined as metals with a density generally more than $5 \mathrm{~g} / \mathrm{cm} 3$, that is five times larger than water. The heavy metals toxicity happens also in low concentrations in the range of $1-10 \mathrm{mg} / 1$. The toxicity resulted from heavy metals is generally caused by strong coordinating abilities [23]. Traditional technologies for removing of heavy metals are known to have specific main disadvantages at heavy metals concentration smaller than $100 \mathrm{mg} / \mathrm{l}$. Problems involve incomplete removal of metal, requirements for costly equipment and controlling systems, high costs of energy or reagent and poisonous sludge creation or other listed waste products. Hence, an efficient new sustainable technology is needed to decrease concentration of heavy metals to environmentally acceptable level at an affordable cost. Lately, biosorption has arisen as an alternate technology for the removing of heavy metals.

Biosorption can be defined as the capability of biological materials to accumulate heavy metals from sewage through physicochemical or metabolically mediated pathways of uptake [7]. The biosorption is a process that utilizes low-cost biosorbents to sequester toxic heavy metals and organic pollutants such as microbial, fungal, seaweed, plant or animal origin [13]. Biosorption has different advantages over the traditional methods which involve: low cost of operating, biomaterial reusability, specific metal selectivity, short time of operation and no chemical sludge. Generally, biosorption is utilized for the treatment of heavy metal pollutants in sewage. Application of biosorption for organic and other pollutants could also be utilized for the sewage treatment [15]. The potential for microorganisms' usage in the metal-bearing sewage treatment has been studied intensively and many microorganisms involving algae, bacteria, fungi, yeast have been found to remove metals and organics from 
solutions. Microorganisms have a high surface area to volume ratio due to their minor size and consequently they can support a large contact interface, which interact with metals from surrounding environment [5]. The cell walls of these microorganisms basically comprise many organic compounds such as chitin, carboxyl, amino acids, acidic polysaccharides, lipids and other components offer numerous functional groups which can bind metal ions such as amine, hydroxyl, carboxylate, etc. Potent metal biosorbents under the class of bacteria involve genre of Bacillus [16; 24], Pseudomonas [4; 25] and Streptomyces $[14 ; 21]$, etc. Important fungal biosorbents includes: Aspergillus [11; 12], Rhizopus [2;19] and Penicillium [17], etc. However, the isolation and growth of a species of microorganisms to remove a pollutant need to culture and provide a suitable nutrient media which is different according to the type of microorganisms. In addition, treatment of a specific kind of metals must coincide with a specific species of microorganisms. For example, Streptococcus equisimilis, Bacillus coagulans and Escherichia coli (bacteria) were used to reduce $\mathrm{Cr}(\mathrm{VI})$ [20], Aspergillus versicolor (fungi) used in the biosorption of $\mathrm{Pb}$ (II) [22].

In the present study, Dead Anaerobic Sludge (DAS) was investigated as a low cost, effective, economic and practicable biosorbent for heavy metals removal. This sludge is a biomass waste created from the regular biological activities of municipal sewage treatment plants. The volume being formed is increased with increasing municipal sewage to be treated, so rather than getting rid of the sludge, considered usage of this waste material appears to be a promising way of turning it into a valuable resource. The microorganisms overgrown in such sewage systems can be used for heavy metal removal as a cheaper and abundant biosorbent. Sludge wastes generated from wastewater systems considered as heterogeneous microorganisms' contents, contain bacteria, fungi, yeast and protozoa.

The objective of this research is to select design of BoxWilson for the optimization of the process factors: agitation speed, $\mathrm{pH}$, initial metal concentration, and biomass dose for high removal efficiency of lead and cadmium from wastewater, by dead anaerobic sludge. Central Composite Design (CCD) was used to discover the effect and relation among process factors to get the abovementioned objective.

\section{Materials and Methods}

\subsection{Material}

\subsubsection{Sorbate}

A standard lead solution with concentration of (1000 $\mathrm{mg} / \mathrm{l})$ was prepared using $\mathrm{Pb}(\mathrm{NO} 3) 2$ salt. A (1.5985 g) of this salt was dissolved in $(1 \mathrm{~L})$ of distilled water and atomic absorption spectrophotometer (AAS) was utilized to measure the specific concentration of metal ion. The prepared solution was kept at room temperature and used as stock solution to prepare various concentrations of $\mathrm{Pb} 2+$ ion.

\subsubsection{Biosorbent}

The anaerobic sludge utilized in the present research was collected as sludge from sewage sludge collection system (Al-Rustamiyah sewage treatment plant, the third extension, Baghdad, Iraq).

To classify species of microorganisms, present in anaerobic sludge, the microorganisms found in the sludge were heterogeneous and consist mainly from facultative anaerobic bacteria, yeast and fungi. Sample were taken to assess its viable bacterial growth by microbiological culture at the laboratories of the Ministry of Environment. The results of the growth are shown in table 1 .

Table 1: Species of microorganisms identified in anaerobic sludge

\begin{tabular}{|c|c|c|c|}
\hline $\begin{array}{l}\text { Species of } \\
\text { Bacteria }\end{array}$ & $\mathrm{CFU} / \mathrm{ml}$ & $\begin{array}{l}\text { Gram- } \\
\text { Positive }\end{array}$ & $\begin{array}{l}\text { Gram- } \\
\text { Negative }\end{array}$ \\
\hline $\begin{array}{c}\text { Coliform } \\
\text { bacteria }\end{array}$ & $>160000$ & & - \\
\hline $\begin{array}{c}\text { Fecal } \\
\text { coliform }\end{array}$ & 160000 & & - \\
\hline $\begin{array}{c}\text { Escherichia } \\
\text { coli }\end{array}$ & 92000 & & - \\
\hline $\begin{array}{c}\text { Enterococcus } \\
\text { faecalis }\end{array}$ & 54000 & + & \\
\hline $\begin{array}{c}\text { Serratia } \\
\text { marcescens }\end{array}$ & 25000 & & - \\
\hline $\begin{array}{l}\text { Proteus } \\
\text { mirabilis }\end{array}$ & 12000 & & - \\
\hline $\begin{array}{l}\text { Species of } \\
\text { Yeast }\end{array}$ & $\mathrm{CFU} / \mathrm{ml}$ & \multicolumn{2}{|c|}{ Species of Fungi } \\
\hline $\begin{array}{l}\text { Candida } \\
\text { albicans }\end{array}$ & 1630 & \multicolumn{2}{|c|}{$\begin{array}{l}\text { Penicillium } \\
\text { chrysogenum }\end{array}$} \\
\hline
\end{tabular}

\subsection{Experimental Design and Data Analysis}

Central Composite Design (CCD), based on four independent process factors was utilized for the optimization of lead removal efficiency. Table 2 shows the Names and Levels of process factors (parameters).

The variables were coded according to equation (1):

$X \_i=\left(x \_i-x \_0\right) /\left(\Delta x \_i\right)$

where, $X \_i$ is the coded value of variable $i, x \_i$ the real value of an independent variable, $x \_0$ the $i$ 'th variable range midpoint value, and $\Delta x \_i$ refers to the change of the limiting two values of the i'th variable. The half value of the difference is the step size. Therefore:

X_1 $=\left(x \_1-6\right) /(2), X \_2=\left(x \_2-30\right) /(10), X \_3=\left(x \_3-3\right) /(1)$, and $X \_\overline{4}=\left(x_{-} 4-200\right) /(50)$ 
CCD in this study is: (i) a complete 24 factorial design, (ii) having center point (n_0) which its value is larger than 1, (iii) having two axial points ( $\left.n_{-} \alpha\right)$ on the axis of every design variable at a distance of $\alpha= \pm \sqrt{K}=2$, where $K$ is the number of variables $(K=4)$. Therefore a total number of design points of $\mathrm{N}=2^{\wedge} \mathrm{K}+2 \mathrm{~K}+\mathrm{n} \_0=\mathrm{n} \mathrm{j}_{+}+\mathrm{n} \_\alpha+\mathrm{n} \_0$ and is obtained from the expression $\bar{N}=\left[\operatorname{star}\right.$ points $\left(n_{-} j\right)$; $\left.n \_j=2^{\wedge} \mathrm{K}=16\right]+\left[\right.$ axial points $\left.\left(n \_\alpha\right) ; n \_\alpha=2 \mathrm{~K}=8\right]+$ [center points (n_0); n_0 $=6$ ]. The levels and names of the four independent process factors, upon which thirty CCD matrices experiments were based, are given in table 2 . While the coded and real level and range values of these variables are shown in table 3 .

Table 1: Names and Levels of process factors (parameters)

\begin{tabular}{|c|c|c|c|c|c|}
\hline Symbol & Parameters name & Abbreviation & Units & Low & High \\
\hline A & $\mathrm{pH}$ & $\mathrm{pH}$ & & 4 & 8 \\
\hline B & Initial metal conc. & INCONC & $\mathrm{mg} / \mathrm{l}$ & 20 & 40 \\
\hline C & Biomass dose & $\mathrm{BD}$ & $\mathrm{g} / \mathrm{l}$ & 2 & 4 \\
\hline D & Agitation speed & AS & $\mathrm{rpm}$ & 150 & 250 \\
\hline
\end{tabular}

Table 3 : Real and coded ranges and levels for independent variables

\begin{tabular}{|c|c|c|c|c|c|}
\hline Independent Parameters & \multicolumn{5}{|c|}{ Ranges and Levels } \\
\hline Coded & -2 & -1 & 0 & +1 & +2 \\
\hline Real & 2 & 4 & 6 & 8 & 10 \\
\hline pH & 10 & 20 & 30 & 40 & 50 \\
\hline INCONC & 1 & 2 & 3 & 4 & 5 \\
\hline BD & 100 & 150 & 200 & 250 & 300 \\
\hline AS & & & & &
\end{tabular}

A quadratic polynomial was fitted to the data of experiments using the statistical software package DesignExpert ${ }^{\circledR}$ Version 11.0 to forecast the dependent variable response and the maximum independent variables values in the biosorption process. The processed quadratic polynomial is given in the following expression

$$
Y=\beta_{0}+\sum_{i=1}^{k} \beta_{i} x_{i}+\sum_{i=1}^{k} \beta_{i i} x_{i}^{2}+\sum_{i=1}^{k-1} \sum_{i=2}^{k} \beta_{i j} x_{i} x_{j}+\varepsilon
$$

where $Y$ is the response, $\beta_{-} 0$ is the intercept (offset) term, $\beta \_\mathrm{i}, \beta \_$ii, $\beta \_$ij are the first-order, quadratic and interaction effects respectively; $i$ and $j$ are the index numbers for a parameter; and $\varepsilon$ is the residual error. This polynomial results in a graphical representation known as Response Surface Methodology (RSM).

\section{Results and Discussion}

\subsection{Statistical Analysis}

Comparison of these values indicated that there was good consensus between experimental and predicted values about the considered range.

The predicted values were gained from the quadratic polynomial using the experimental values and using multiple linear regressions. Analysis of variance, using Design-Expert ${ }^{\circledR}$ Version 11.0 software, was implemented to evaluate the significance of fit of the quadratic polynomial.

All the readings of lead removal efficiencies (listed in table 4), were processed by ANOVA. A second degree polynomial model was fitted with these readings. Second order polynomial models gained in this study were used for each response to obtain the optimum conditions 
Table 4 : The predicted lead removal efficiency in the system at the same conditions of the experimental readings

\begin{tabular}{|c|c|c|c|c|c|c|c|c|c|c|}
\hline \multirow[b]{2}{*}{ Run } & \multicolumn{4}{|c|}{ Coded values } & \multicolumn{4}{|c|}{ Actual values } & \multicolumn{2}{|c|}{ Response } \\
\hline & $\mathrm{X}_{1}$ & $\mathrm{X}_{2}$ & $\mathrm{X}_{3}$ & $\mathrm{X}_{4}$ & $\begin{array}{l}\mathrm{A}: \\
\mathrm{pH}\end{array}$ & $\begin{array}{c}\text { B: } \\
\text { INCONC } \\
(\mathrm{mg} / \mathrm{l})\end{array}$ & $\begin{array}{c}\mathrm{C}: \\
\mathrm{BD} \\
(\mathrm{g} / \mathrm{l})\end{array}$ & $\begin{array}{c}\mathrm{D}: \\
\mathrm{AS} \\
(\mathrm{rpm})\end{array}$ & $\begin{array}{c}\text { Expected } \\
\mathrm{R} \text {. of } \mathrm{Pb} \\
(\%)\end{array}$ & $\begin{array}{c}\text { Predicted } \\
\text { R. of } \mathrm{Pb} \\
(\%)\end{array}$ \\
\hline 1 & 1 & 1 & -1 & -1 & 8 & 40 & 2 & 150 & 57.44 & 53.284 \\
\hline 2 & 1 & -1 & -1 & 1 & 8 & 20 & 2 & 250 & 63.4 & 60.844 \\
\hline 3 & 0 & -2 & 0 & 0 & 6 & 10 & 3 & 200 & 88.8144 & 87.23 \\
\hline 4 & 2 & 0 & 0 & 0 & 10 & 30 & 3 & 200 & 30.263 & 34.31 \\
\hline 5 & 1 & -1 & 1 & -1 & 8 & 20 & 4 & 150 & 64.35 & 63.816 \\
\hline 6 & 0 & 0 & -2 & 0 & 6 & 30 & 1 & 200 & 58.233 & 63.55 \\
\hline 7 & 1 & -1 & -1 & -1 & 8 & 20 & 2 & 150 & 56.563 & 56.336 \\
\hline 8 & -1 & 1 & -1 & 1 & 4 & 40 & 2 & 250 & 65.945 & 63.136 \\
\hline 9 & -1 & 1 & 1 & -1 & 4 & 40 & 4 & 150 & 65.352 & 64.564 \\
\hline 10 & 1 & 1 & 1 & -1 & 8 & 40 & 4 & 150 & 64.922 & 62.084 \\
\hline 11 & -1 & -1 & -1 & 1 & 4 & 20 & 2 & 250 & 68.275 & 68.844 \\
\hline 12 & -1 & 1 & -1 & -1 & 4 & 40 & 2 & 150 & 60.341 & 57.244 \\
\hline 13 & 0 & 0 & 0 & 0 & 6 & 30 & 3 & 200 & 89.34 & 91.15 \\
\hline 14 & 0 & 0 & 0 & -2 & 6 & 30 & 3 & 100 & 52.43 & 56.11 \\
\hline 15 & 0 & 0 & 2 & 0 & 6 & 30 & 5 & 200 & 78.429 & 78.75 \\
\hline 16 & 0 & 0 & 0 & 0 & 6 & 30 & 3 & 200 & 92.42 & 91.15 \\
\hline 17 & 1 & 1 & -1 & 1 & 8 & 40 & 2 & 250 & 60.51 & 58.096 \\
\hline 18 & 1 & 1 & 1 & 1 & 8 & 40 & 4 & 250 & 69.12 & 67.296 \\
\hline 19 & -1 & -1 & 1 & -1 & 4 & 20 & 4 & 150 & 69.118 & 69.256 \\
\hline 20 & 0 & 0 & 0 & 0 & 6 & 30 & 3 & 200 & 94.7143 & 91.15 \\
\hline 21 & -1 & 1 & 1 & 1 & 4 & 40 & 4 & 250 & 72.891 & 70.856 \\
\hline 22 & 0 & 0 & 0 & 0 & 6 & 30 & 3 & 200 & 88.72 & 91.15 \\
\hline 23 & -1 & -1 & 1 & 1 & 4 & 20 & 4 & 250 & 74.434 & 75.244 \\
\hline 24 & 0 & 0 & 0 & 2 & 6 & 30 & 3 & 300 & 65 & 66.91 \\
\hline 25 & -1 & -1 & -1 & -1 & 4 & 20 & 2 & 150 & 64.795 & 63.256 \\
\hline 26 & -2 & 0 & 0 & 0 & 2 & 30 & 3 & 200 & 43.235 & 44.79 \\
\hline 27 & 0 & 2 & 0 & 0 & 6 & 50 & 3 & 200 & 72.619 & 79.79 \\
\hline 28 & 0 & 0 & 0 & 0 & 6 & 30 & 3 & 200 & 90.3 & 91.15 \\
\hline 29 & 1 & -1 & 1 & 1 & 8 & 20 & 4 & 250 & 67.91 & 68.724 \\
\hline 30 & 0 & 0 & 0 & 0 & 6 & 30 & 3 & 200 & 91.4126 & 91.15 \\
\hline
\end{tabular}

Mathematical expression for the system of relationship to the response with variables (in terms of coded factors) is given below:

Removal of $\mathrm{Pb}(\%)=91.15-2.62(\mathrm{~A})-1.86(\mathrm{~B})+3.80(\mathrm{C})$ $+2.70(\mathrm{D})+0.74(\mathrm{AB})+0.37(\mathrm{AC})-0.27(\mathrm{AD})+0.33(\mathrm{BC})$ $+0.076(\mathrm{BD})+0.10(\mathrm{CD})-12.9(\mathrm{~A} 2)-1.91(\mathrm{~B} 2)-5(\mathrm{C} 2)-$ 7.41(D2)

By comparison experimental and predicted readings, the results show a good matching in the defined range. ANOVA analysis shows the magnitude of F-values (32.68) and the low probability value $(<0.0001)$, proof the significant model fit. Furthermore, the model's R2 $=0.97$, which is acceptable. R2 $>0.75$ indicates aptness of the model. Also most values of (Probability $>$ F) were smaller than 0.05 , which confirms that the terms of model are significant. A good explain for that is the linear coefficient $x_{-} i$, the quadratic coefficients $x \_i x \_j$, and the coefficient of $\left[x \_i \rrbracket \wedge 2\right.$ in equation (3) are all significant with a $95 \%$ probability. Adequate precision measures the signal-tonoise ratio. A ratio larger than 4 is desirable. Ratios of 21.472 indicate an adequate signal. This model, therefore, can be utilized for the design space navigation. 


\subsection{Three-Dimensional Graphical Representation of Lead Ion Removal Optimization}

To clarify the best conditions for lead ion removal, the quadratic polynomial model was utilized to create response surface plots by response surface method. The three-dimensional plots were generated by keeping two of the variables constant at their midpoints and altering the other two variables within their experimental range. The results of response surfaces depicted the effect of $\mathrm{pH}$, initial metal concentration, agitation speed, and biomass dose on biosorption of sludge.
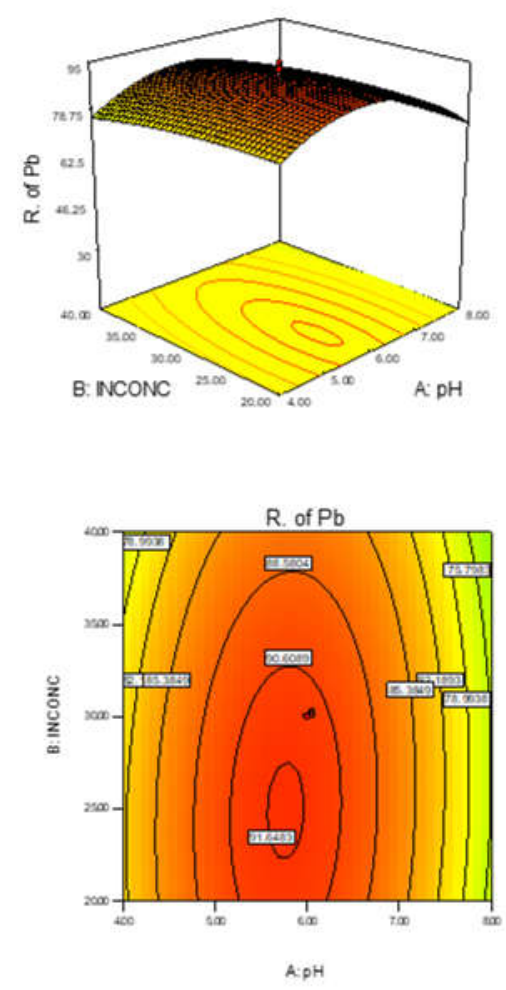

Figure 1: Interaction influences of $\mathrm{pH}$ and initial concentration on lead removal: surface plot; contour plot

This plateau is depicted by the innermost contour. The plateau's peak coincides with lead removal efficiency of $91.6483 \%$. This is in conformity with finding Öztürk et al (2014) [18]. The biosorption capacity increased with increasing metals initial concentration. With increasing concentration of metal ion, there is an increase in the amount of metal ion adsorbed due to increasing the driving force of the metal ions toward the active sites on the adsorbent [1]. The available pores become insufficient to adsorb, further lead ions are left in suspension. Similar observation is reported in literature [6]. The effect of initial lead concentration and $\mathrm{pH}$ on the removal efficiency for the system is presented by fig. 1. Fig. 1 shows that a highremoval efficiency plateau occurs in the surface over a lead concentration range of $(22.34-27.5 \mathrm{mg} / \mathrm{l})$ and a $\mathrm{pH}$ range of $(5.57-5.96)$. The low adsorption capacity was at $\mathrm{pH}$ below 5.57 is due to the increase in positive charge density on the surface site, thus electrostatic repulsion occurs between lead ions and the functional groups with positive charge on the surface, then adsorption capacity decreased with increasing $\mathrm{pH}$, this is due to the negative charge density on biosorbent surface increases as a result of deprotonation of the metal binding sites. Similar comment was made in Hao et al (2014) [9].

Fig. 2 depicts the response surface representing the interaction between $\mathrm{pH}$-value and biomass dose on lead removal efficiency in the system. A plateau exists over $\mathrm{pH}$ value and biomass dose ranges between $(5.49-6.13)$ and $(3.12-3.63 \mathrm{~g} / \mathrm{l})$, respectively. The plateau's peak corresponds to a lead removal efficiency of $91.6483 \%$. Hasan et al (2009) found that the maximum removal efficiency for lead was at pH 5 and at biomass dose $20 \mathrm{~g} / \mathrm{l}$.
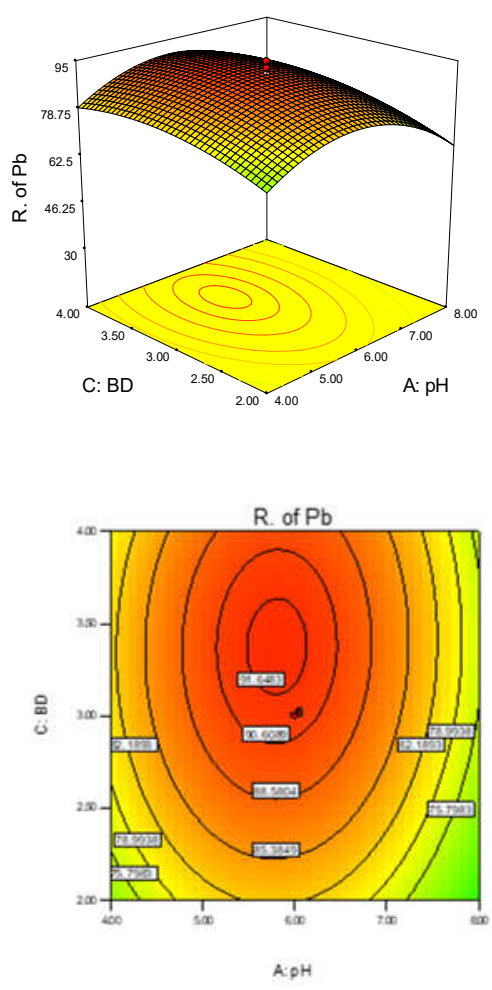

Figure 2: Interaction influences of $\mathrm{pH}$ and biomass dose on lead ion removal: surface plot; contour plot.

The interaction of agitation speed and $\mathrm{pH}$-value on lead ion removal efficiency in the system is depicted, as response surface and contour plot, as can be seen in fig. 3 . The highremoval efficiency plateau corresponds to agitation speed range of $(191.6-226.59 \mathrm{rpm})$ and $\mathrm{pH}$ range of (5.26 6.33). The biosorption capacity increasing with increasing of agitation speed due to the increased turbulence and consequently reducing the boundary layer thickness around the biosorbent particles resulted from the increasing of the mixing degree [27]. A relatively high lead removal $(94.53 \%)$ in Cerino et al (2011) [3] was predicted at $\mathrm{pH} 5.2$ and $102 \mathrm{rpm}$. 

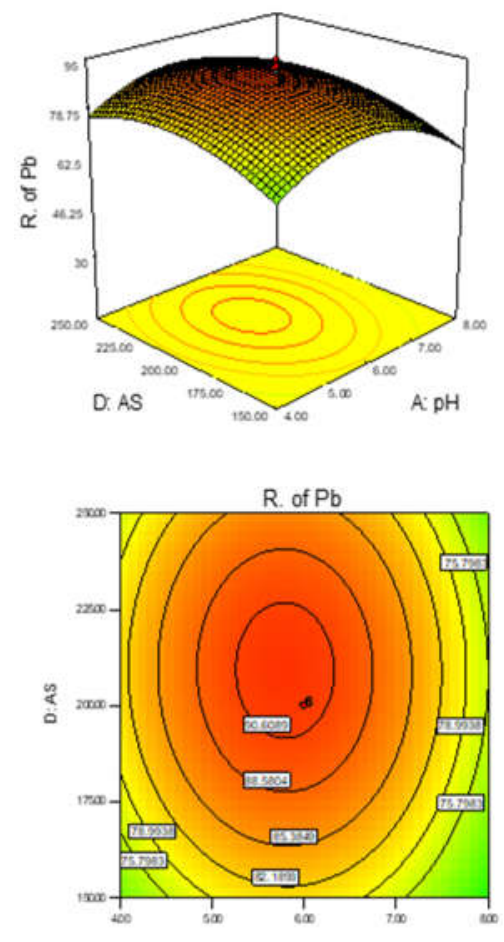

A.PH

Figure 3: Interaction influences of $\mathrm{pH}$ and agitation speed on lead removal: surface plot; contour plot.

The interaction of initial lead ion concentration and biomass dose on lead ion removal efficiency in the system is depicted, as response surface and contour plot, in fig. 1 . The high-removal efficiency plateau corresponds to initial lead ion concentration range of $(23.51-27.33 \mathrm{mg} / \mathrm{l})$ and biomass dosage ranges of $(3.24-3.48 \mathrm{~g} / \mathrm{l})$.
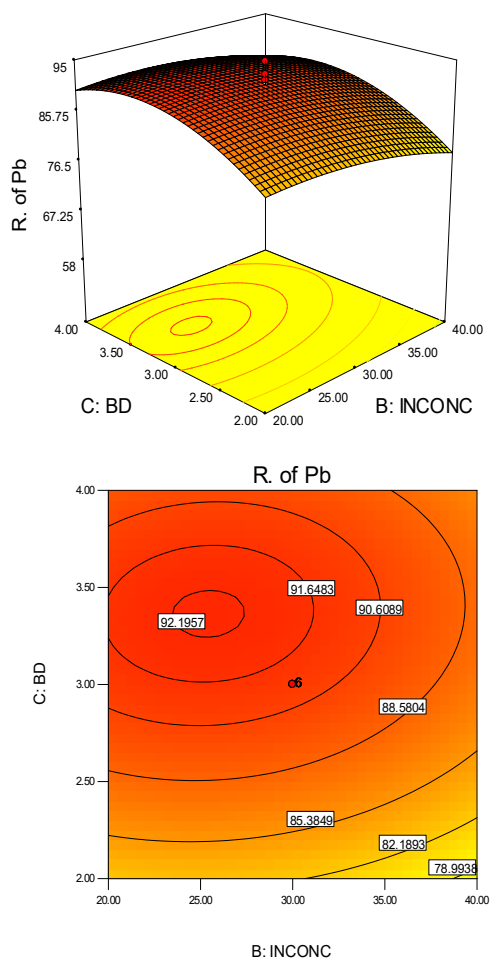

Figure 1: Interaction influences of biomass dose and initial concentration on lead removal: surface plot; contour plot
Fig. 2 shows The interaction of initial lead concentration and agitation speed on lead removal efficiency in the system is depicted, as response surface and contour plot. The high-removal efficiency plateau corresponds to initial lead concentration range of $(21.98-28.32 \mathrm{mg} / \mathrm{l})$ and agitation speed range of $(200.97-217.02 \mathrm{rpm}) .150 \mathrm{mg} / \mathrm{l}$ and $180 \mathrm{rpm}$ are the initial lead concentration and agitation speed, respectively, required for the high-removal efficiency of lead in Garba et al (2016) [8].
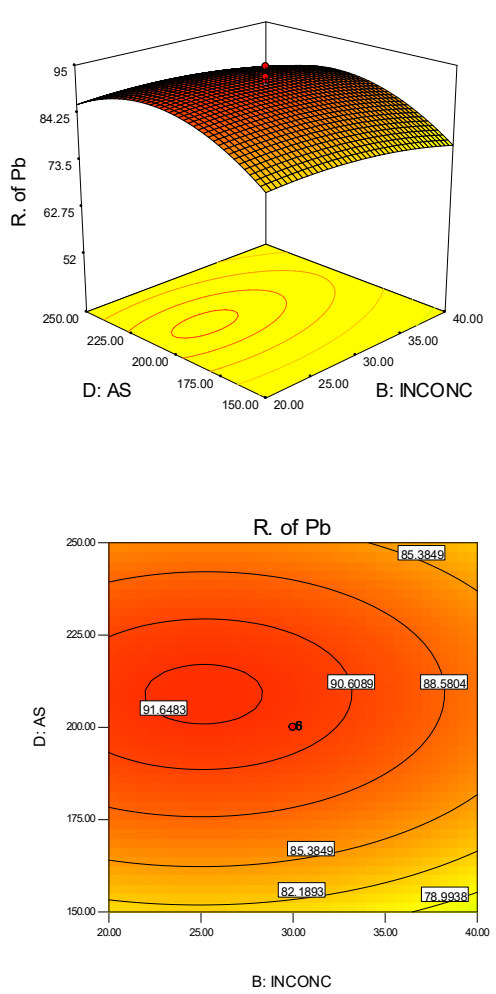

Figure 2: Interaction influences of initial concentration and agitation speed on lead removal: surface plot; contour plot

Fig. 3 shows The interaction of biomass dose and agitation speed on lead removal efficiency for the system. It can be seen from this fig. that to achieve high-removal efficiency, biomass dose should be in the range of $(3.08-$ $3.69 \mathrm{~g} / \mathrm{l})$ and the agitation speed should also be the range of $(196.66-221.8 \mathrm{rpm})$. 

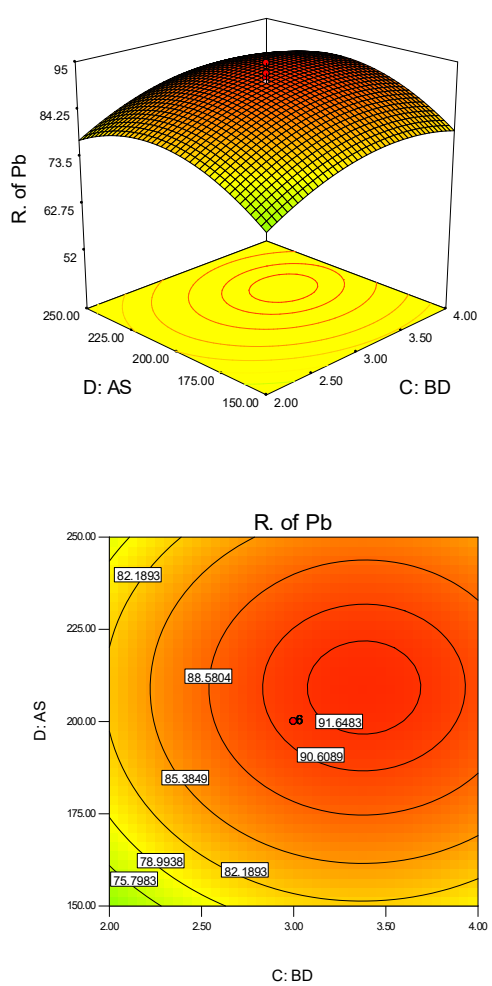

Figure 3: Interaction effects of agitation speed and biomass dose on lead removal: surface plot; contour plot.

The curves of response surface were plotted to find the variables interaction and to find the best conditions for percentage of removal of lead ions using sludge biomass. The optimum values, gained by substituting the respective coded values of variables in equation (Error! Reference source not found.), are: $\mathrm{pH}$ (5.78), initial metal concentration $(25.29 \mathrm{mg} / \mathrm{l})$, biomass dose $(3.36 \mathrm{~g} / \mathrm{l})$ and agitation speed $(209.21 \mathrm{rpm})$. At these conditions, the maximum percentages for lead removal was calculated. The optimal values predicted were found to be within the design region. This showed that the model acceptably explains the influence of the selected variables on the percentage removal of metal.

\section{Conclusion}

Response surface methodology and ANOVA have been studied by using Design-Expert ${ }^{\circledR}$ software to find the best conditions for maximum removal of lead ion from wastewater, and by using quadratic polynomial, the conditions were calculated. The best conditions that obtained for maximum removal of lead ion from wastewater were $\mathrm{pH}$ 5.78, initial metal concentration 25.29 $\mathrm{mg} / \mathrm{l}$, biomass dose $3.36 \mathrm{~g} / \mathrm{l}$, and agitation speed 209.21 rpm.

\section{References}

1. Abdel-Ghani, N. \& El-Chagbaby, G. (2014) Biosorption for metal ions removal from aqueous solutions: A review of recent studies. International Journal of Latest Research in Science and Technology, 3(1), 24-42.

2. Bai, R. S. \& Abraham, T. E. (2002) Studies on enhancement of $\mathrm{Cr}(\mathrm{VI})$ biosorption by chemically modified biomass of Rhizopus nigricans. Water Research, 36(5), 1224-1236.

3. Cerino, F., M. García León, A., García-Reyes, R., Garza-González, M., Soto-Regalado, E., N. Sánchez González, M. \& Quezada López, I. (2011) Response surface methodology for lead biosorption on Aspergillus terreus. International Journal of Environmental Science \& Technology, 8(4), 695-704.

4. Chang, J.-S., Law, R. \& Chang, C.-C. (1997) Biosorption of lead, copper and cadmium by biomass of Pseudomonas aeruginosa PU21. Water Research, 31(7), 1651-1658.

5. Deng, S. \& Ting, Y. P. (2007) Removal of As(V) and As(III) from water with a PEI-modified fungal biomass. Water Science \& Technology, 55(1-2), 177-185.

6. Ekebafe, L. O., Ogbeifun, D. E., Okieimen, F. E. \& Amenaghawon, A. N. (2017) Response Surface Methodology for the Competitive Sorption of Metal ions from Aqueous Medium using Starch-Graft-Copolymer. Trade Science, 12(2), 1-18.

7. Fard, R. F., Azimi, A. A. \& Bidhendi, G. R. N. (2012) Batch kinetics and isotherms for biosorption of cadmium onto biosolids. Desalination and Water Treatment, 28(13), 69-74.

8. Garba, Z. N., Bello, I., Galadima, A. \& Lawal, A. Y. (2016) Optimization of adsorption conditions using central composite design for the removal of copper (II) and lead (II) by defatted papaya seed. Karbala International Journal of Modern Science, 2(1), 20-28.

9. Hao, X., Mohamad, O. A., Xie, P., Rensing, C. \& Wei, G. (2014) Removal of Zinc from Aqueous Solution by Metal Resistant Symbiotic Bacterium Mesorhizobium amorphae. Separation Science and Technology, 49(3), 376-387.

10. Hasan, S. H., Srivastava, P. \& Talat, M. (2009) Biosorption of $\mathrm{Pb}$ (II) from water using biomass of Aeromonas hydrophila: Central composite design for optimization of process variables. Journal of Hazardous Materials, 168(2), 1155-1162.

11. Jianlong, W., Xinmin, Z., Decai, D. \& Ding, Z. (2001) Bioadsorption of lead(II) from aqueous solution by fungal biomass of Aspergillus niger. Journal of Biotechnology, 87(3), 273-277.

12. Kapoor, A. \& Viraraghavan, T. (1997) Heavy metal biosorption sites in Aspergillus niger. Bioresource Technology, 61 (3), 221-227. 
13. Kratochvil, D. \& Volesky, B. (1998) Advances in the biosorption of heavy metals. Trends in Biotechnology, 16(7), 291-300.

14. Mameri, N., Boudries, N., Addour, L., Belhocine, D., Lounici, H., Grib, H. \& Pauss, A. (1999) Batch zinc biosorption by a bacterial nonliving Streptomyces rimosus biomass. Water Research, 33(6), 1347-1354.

15. Mungasavalli, D. P., Viraraghavan, T. \& Jin, Y.-C. (2007) Biosorption of chromium from aqueous solutions by pretreated Aspergillus niger: Batch and column studies. Colloids and Surfaces A: Physicochemical and Engineering Aspects, 301(1-3), 214-223.

16. Nakajima, A. \& Tsuruta, T. (2004) Competitive biosorption of thorium and uranium by Micrococcus luteus. Journal of Radioanalytical and Nuclear Chemistry, 260(1), 13-18.

17. Niu, H., Xu, X. S., Wang, J. H. \& Volesky, B. (1993) Removal of lead from aqueous solutions by Penicillium biomass. Biotechnology and Bioengineering, 42(6), 785787.

18. Öztürk, D., Şahan, T., Dişli, E. \& Aktaş, N. (2014) Optimization with response surface methodology (RSM) of adsorption conditions of $\mathrm{Cd}(\mathrm{II})$ ions from aqueous solutions by pumice. Hacettepe Journal of Biology and Chemistry, 42(2), 183-192.

19. Park, D., Yun, Y.-S. \& Park, J. M. (2005) Use of dead fungal biomass for the detoxification of hexavalent chromium: screening and kinetics. Process Biochemistry, 40(7), 2559-2565.

20. Quintelas, C., Fernandes, B., Castro, J., Figueiredo, H. \& Tavares, T. (2008) Biosorption of $\mathrm{Cr}(\mathrm{VI})$ by three different bacterial species supported on granular activated carbon-A comparative study. Journal of Hazardous Materials, 153(1), 799-809.

21. Selatnia, A., Bakhti, M. Z., Madani, A., Kertous, L. \& Mansouri, Y. (2004) Biosorption of Cd2+ from aqueous solution by a $\mathrm{NaOH}$-treated bacterial dead Streptomyces rimosus biomass. Hydrometallurgy, 75(1-4), 11-24.

22. Tan, T. \& Cheng, P. (2003) Biosorption of metal ions with Penicillium chrysogenum. Applied Biochemistry and Biotechnology, 104(2), 119-128.

23. Tarangini, K. (2009) Biosorption of Heavy Metals Using Mixed Cultures of Pseudomonas Aeruginosa and Bacillus Subtilis. MTech by Research National Institute of Technology Rourkela.

24. Tunali, S., Çabuk, A. \& Akar, T. (2006) Removal of lead and copper ions from aqueous solutions by bacterial strain isolated from soil. Chemical Engineering Journal, 115(3), 203-211.

25. Uslu, G. \& Tanyol, M. (2006) Equilibrium and thermodynamic parameters of single and binary mixture biosorption of lead (II) and copper (II) ions onto Pseudomonas putida: Effect of temperature. Journal of Hazardous Materials, 135(1-3), 87-93.

26. Vijayaraghavan, K. \& Yun, Y.-S. (2008) Bacterial biosorbents and biosorption. Biotechnology Advances, 26(3), 266-291.

27. Zahoor, M. (2011) Effect of Agitation Speed on Adsorption of Imidacloprid on Activated Carbon. Journal of the Chemical Society of Pakistan, 33(3), 305-312. 


\section{لمين التجارب للإمتز از الحيوي لأيونات الرصاص من المياه الملوّثة بطريقة بوكس - ولسن}

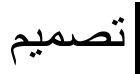

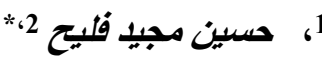

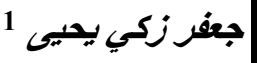
jaafaraladily@yahoo.com، قسم الهندسة البيئية، جامعة بغداد ، بغداد، العراق hussmf200211@yahoo.com، قسم الهندسة البيئية، جامعة بغداد ، بغداد، العراق jaafaraladily@yahoo.com:"الباحث المثل: جعفر زكي يحيى ، البريب الاكتتروني نشر في: 30 حزيران 2019

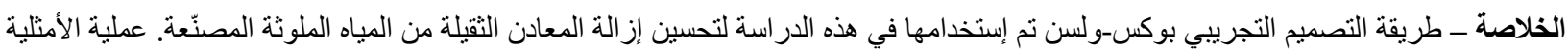

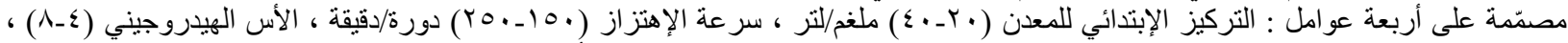

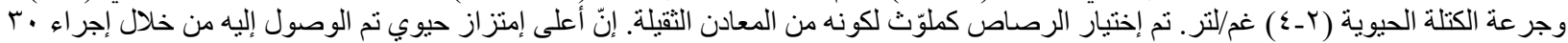

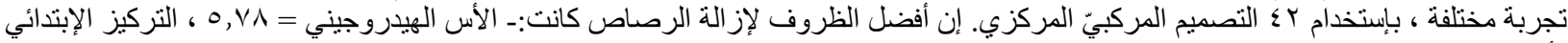

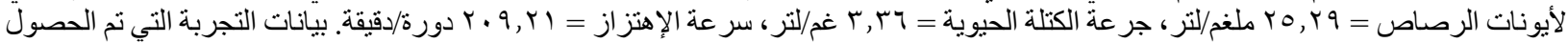

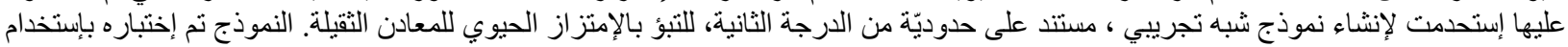

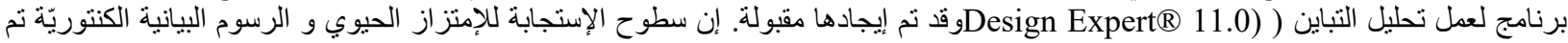

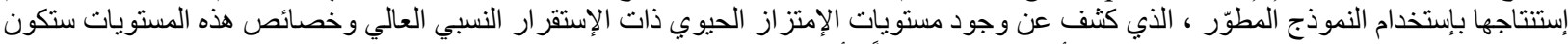
مفيدة في السيطرة على الوحدات بقياس مختبري أو صناعي مستقبلاً لتأكيد الإمكانية الإقتصادية الإنية. الكلمات الرئيسية ـ الأمثلية ، أيون الرصاص ، الحمأة اللاهو ائية الميتة ، منهجية سطح الإستجابة ، تحليل التباين. 